\title{
REFLAGGING KUWAITI TANKERS: A U.S. RESPONSE IN THE PERSIAN GULF
}

Since September 1986, Iranian air attacks on Persian Gulf shipping have focused on Kuwaiti vessels and vessels bound for Kuwaiti ports. Iran singled out Kuwait partially in retaliation for the aid Kuwait has given to Iraq during the course of the eight-year war between Iran and Iraq. ${ }^{1}$ In response to escalating attacks on its shipping, Kuwait sought assistance from the United States and the Soviet Umon in protecting its vessels and nraritine commerce. ${ }^{2}$ In March 1987, the United States responded by reflagging eleven Kuwaiti oil tankers as Umited States vessels. ${ }^{3}$

Reflagging the tankers changed the nationality of the vessels from Kuwaiti to U.S., entitling the tankers to United States naval protection. As of the writing of this note, all eleven reflagged tankers are transiting the Persian Gulf escorted by United States warships. ${ }^{4}$ Although the convoys have not been challenged or attacked directly, ${ }^{5}$ two of the vessels have encountered the major risks the Iran-Iraq War poses to commercial shipping in the Gulf-mines and air attacks. ${ }^{6}$

Large nunibers of mines appeared in the Persian Gulf about the time the United States began its convoys of the reflagged tankers. ${ }^{7}$ That Iran was responsible, at least partially, was finally proven when United States special forces on naval helicopters located, photographed, then attacked an Iranian vessel unloading mimes into an international shippimg lane in

1. See Defense Policy Panel \&z the Investigations Subcomm. of the House Comm. on Armed Services, 100th Cong., 1st Sess., National Securtry Policy Implications of United States Operations in the Persian Gulf 7-9 (Comm. Print 1987). The report also cited other reasons why Iran singled out Kuwait: (1) Kuwait is small and easily pressured; and (2) Kuwait is less willing to cooperate with Tehran on issues of oil policy. Id. at 8-9.

2. See 133 CoNG. REC. E2646-47 (daily ed. June 26, 1987) (statement of Rep. Aspin).

3. C. Weinberger, A Report to the Congress on Security Arrangements in the Persian Gulf, at ii (June 15, 1987).

4. Convoy to a Minefield, MACLEAN's, Aug. 3, 1987, at 20-21.

5. In the Gulf, Nowhere to Hide, NEwSWEEK, Sept. 14, 1987, at 44.

6. On July 24, 1987, the reflagged Kuwaiti tanker Bridgeton struck a mine 120 miles southeast of Kuwait on its maiden voyage under the U.S. flag. See Convoy to a Minefield, supra note 4, at 2021. On October 15, 1987, the U.S.-flagged Sea Isle City was hit by an Iranian-fired Silkworm missile while in Kuwait's territorial waters, unescorted by U.S. warships. United States Reprisal Against Iran, 23 WeEkLy COMP. Pres. Doc. 1206 (Oct. 20, 1987). For a discussion of the legal implications of Iranian and Iraqi air attacks on merchant shipping, see Note, Air Attacks on Neutral Shipping in the Persian Gulf: The Legality of the Iraqi Exclusion Zone and Iranian Reprisals, 8 B.C. INT'L \& COMP. L. REv. 517 (1985).

7. The Mines of August, NEwSwlsek, Aug. 24, 1987, at 22. 
the Gulf. An examination of the mines on board the Iranian vessel disclosed that the mines were similar to others previously discovered throughout the Gulf. ${ }^{8}$

This note first examines the legality of the Kuwaiti tanker reflagging under international and domestic standards. The discussion traces the development of the international standard-the "genuine link" - for reflagging and the domestic implennentation of the international requirements for reflagging. The note then analyzes the validity of the reflagging under both standards and suggests that the vagueness of the genuine hink language in international conventions permits nations to employ reflagging to suit their own objectives as long as the implementation ineets certain minimum standards. ${ }^{10}$ The United States has taken full advantage of the vagueness of the genuine link requirement, using the reflagged vessels to achieve broader pohtical objectives in the Persian Gulf. Nevertheless, to the extent that the genuine link requirement connotes some degree of flag state control over the administrative, technical, and social inatters of a vessel, the reflagging satisfies the minimum standards of international maritime law.

The note next examines the state practice implications of the reflagged tankers' movement under convoy through the Gulf. When states act contrary to international law standards, states whose interests are harmed by the violation are entitled to seek a resolution through peaceful means and, if necessary, to protect their interests. ${ }^{11}$ Efforts to seek a peaceful end to the Iran-Iraq War through United Nations Security Council resolutions have failed. ${ }^{12}$ In the meantime, the United States

8. Caught in the Act, TIME, Oct. 5, 1987, at 20-22.

9. "Genuine link" is a term used in international and maritime law to describe the contacts linking a vessel to the state whose flag it flies. The term "genuine link" originally arose in the context of determining the nationality of a person. Nottebohm Case (Liclit. v. Guat.), 1955 I.C.J. 4, 23. The transfer of the idea to the maritime area was suggested by the Netherlands Government in 1956 and later adopted by the International Law Commission in its draft articles on the regine of the high seas that eventually became the 1958 Convention ou the High Seas. See Summary Records of the 341st Meeting, [1956] 1 Y.B. INT'L L. CoMm'N 36, 37-38, U.N. Doc. A/2934/1956 A/CN.4/ 97 \& Add. 1, A/CN.4/99 \& Add. 1-5; Regime of the High Seas and Regime of the Territorial Sea, [1956] 2 Y.B. INT'L L. CoMm'N 1, 62-63, U.N. Doc. A/CN.4/99/Add.1.

10. See infra notes $59-90$ and accompanying text.

11. See infra notes 107-14 and accompanying text.

12. The United Nations Security Council passed a unanimous resolution on July 20, 1987, calling for an immediate ceasefire in the Iran-Iraq War. U.N.S.C. Res. 598 (1987), reprinted in Iran-Iraq War and Navigation in the Gulf [May 17-August 11, 1987], 26 INT'L LEGAL MATERIALS $1422,1479-80$ (1987). Iran responded to the resolution saying in part, "Resolution 598 (1987) has been formulated and adopted by the United States with the explicit intention of intervention in the Persian Gulf and the region, mustering support for Iraq and its supporters in the war." Letter dated August 11, 1987 fron the Permanent Representative of the Islamic Republic of Iran to the United Nations Addressed to the Secretary-General, U.N. Doc. S/19031, Aug. 11, 1987, reprinted in IranIraq War and Navigation in the Gulf, supra, at 1481. The Iranian response noted that the Security 
and allies have increased the number of naval forces in the Gulf. ${ }^{13}$ The forces serve two purposes: first, the more immediate purpose of protecting shipping and second, the more important purpose of visible protest. The Persian Gulf maneuvers establish a state practice precedent of cooperative efforts to protect the freedom of navigation and deter illegal activities impeding that freedom.

The note analyzes the United States' response to the mining of Persian Gulf waters. When minesweeping activity can deactivate mines, states should seek that avenue of resolution. When evidence of imining is so clear as to leave no opportunity for a negotiated cessation of mining activities, those threatened by mines should take action to prevent further unlawful sowing of mines. The United States did so when it attacked an Iranian minelayer. In all cases in which there is clear evidence of mining that has caused daniage, states should press claims for compensation agamst the perpetrator.

This note concludes that, apart from whatever more immediate and debatable foreign policy ends the reflagging serves, the movement of the United States convoys in the Persian Gulf serves the important function under international law of effective state protest against illegal Iraman and Iraqi actions. ${ }^{14}$ The presence of neutral vessels trading in the Gulf manifests the intent of 'neutral states to protect and enforce customary rights of trading and free navigation. Without effective protest against actions clearly unjustifiable under imternational law, the danger exists that the illegal practices will become precedents, moving state practice further from the pacifistic goals of the Umited Nations Charter. ${ }^{15}$

Council did not act when Iran was attacked by Iraq and that by passing the resolution, the Security Council was acting at the behest of the United States, turning it into a party to the conflict. Letter dated Aug. 11, 1987, reprinted in Iran-Iraq War and Navigation in the Gulf, supra, at 1482. The letter concluded by commending the Secretary-General on his independent initiatives, expressing the desire to continue cooperating with him. Id. at 1484. The Iraqi Government responded that it welcoined the resolution and was willing to cooperate in implementing a settlement with Iran. Letter dated August 14, 1987 from the Charge D'Affaires A.I. of the Permanent Mission of Iraq to the United Nations Addressed to the Secretary-General, U.N. Doc. S/19045, Aug. 14, 1987, reprinted in Iran-Iraq War and Navigation in the Gulf [May 17-August 11, 1987] 26 INT'L LEGAL MATERIALS 1422, 1485 (1987).

13. The United States has maintained some naval forces in the Persian Gulf since 1949. The size of its naval presence in the Gulf increased dramatically when the Umited States agreed to reflag and escort the Kuwaiti tankers. The mcremental increase in cost of operations in and around the Gulf arising froin the increased presence was estimated to be $\$ 69$ million for July through Septeinber, 1987. R. O'Rourke, Persian Gulf: U.S. Milttary Operamons 4-7 (Congressional Research Serv. No. IB87145, 1987).

14. See infra notes $103-15$ and accompanying text.

15. The text of the United Nations Charter can be found at 59 Stat. 1031, T.S. 993. 


\section{The Legal Standards for Reflagging}

The flag of a vessel serves two different functions: it is a symbol of the nationality of the ship, consequently designating the national law that governs the affairs of the vessel, and it identifies the location of those responsible for the vessel. ${ }^{16}$ Although hability for the vessel's actions and affairs rests with the owner, responsibility for ensuring that the vessel meets certain international standards rests with the nation granting the vessel its flag. ${ }^{17}$

Some states offer vessel registration under conditions that impose fewer financial and administrative burdens than are imposed by other states. Thus, economic, rather than political considerations usually account for an owner's decision to flag or reflag a vessel under a particular state's flag. ${ }^{18}$ The considerations behind the Kuwaiti request to reflag eleven of its tankers and the United States' response in granting that request were, however, quite the opposite. The Kuwaiti request arose from the imniediate political and strategic concern of thwarting further Iranian attacks on its vessels. Given the exigencies of the situation, this reflagging represents "an unusual measure to meet an extraordinary situation," 19 not a typical flagging transaction.

Regardless of the United States' motives, the reflagging must be justifiable on its own merits as a reflagging under the international and domestic standards that govern vessel registration. ${ }^{20}$ The international standard is embodied in the concept of the genuine link that was addressed in three separate conventions. ${ }^{21}$ The Umited States has accepted one of those conventions and implemented its requirements in large part in the Vessel Docunientation Act. ${ }^{22}$

16. N. Singh, Maritime Fiag ANd INTERnational LaW 3 (1978).

17. See infra notes 23-54 and accompanying text.

18. See B. Boczex, Flags of ConVEnience: AN International Legal Study 26-36 (1962) (discussing the cconomic advantages offered by the "Panlibhon" states-Panama, Liberia, and Honduras); Comment, Vessel Registration in Selected Open Registries, 6 MAR. LAw. 221, 22225 (1981).

19. United States Dep't of STate, Current Policy No. 958, INTERnational Shipping AND THE IRAN-IRAQ WAR 2 (1987).

20. The Reagan administration has based the propriety of its increased presence in the Persian Gulf in part on the well-accepted principle that states are entitled to protect vessels flying their flag. The first step in analyzing the event is to determine whether the United States properly attributed its flag to the tankers.

21. The first was the Convention on the High Seas, opened for signature Apr. 29, 1958, 13 U.S.T. 2312, T.I.A.S. No. 5200, 450 U.N.T.S. 82 [hereinafter 1958 Convention]; the second was the United Nations Convention on the Law of the Sea, opened for signature Dec. 10, 1982, AV CONF.62/122 (1982) [hereinafter UNCLOS]; and the third was United Nations: Convention on Conditions for Registration of Ships, art. 9, para. 1 (1986) [hereinafter 1986 Convention].

22. Pub. L. No. 96-594, 94 Stat. 3453 (1980) (codified as amended in scattered sections of 46 U.S.C.). 


\section{A. International Standards for Reflagging: The Genuine Link.}

What constitutes a sufficiently genuine link between vessel and state under international law has been the source of continued controversy since the genuine link concept's incorporation into maritime law in 1958.23 Three conventions have addressed the issue of vessel nationality ${ }^{24}$ and, although all three require that a genuine link exist as a condition to flagging a vessel, none have specifically defined its content. This section traces the development of the genuine link in order to assess the reflagging action both under the specific standard applicable to the United States by virtue of its acceptance of the first convention ${ }^{25}$ and under the current trend of world opimion as embodied in the latest convention. ${ }^{26}$

1. The 1958 Convention on the High Seas. The genuine link concept was first officially apphed to vessels and codified in the First United Nations Convention on the Law of the Sea's 1958 Convention on the High Seas (1958 Convention). ${ }^{27}$ The debate over the conditions under which a state could flag vessels as its own had become increasingly divisive after World War II, ${ }^{28}$ separating the traditional maritime powers from those developing countries that allowed vessels to fly their national flag without imposing strict requireinents on vessel owners. ${ }^{29}$ The adininistrative and economic convenience of registering vessels under these less burdensoine regimes led to the use of the term "flag of convenience" to denote these states. ${ }^{30}$ The 1958 Convention intended to redress the perceived problems caused by flag of convenience regimes.

23. See Tache, The Nationality of Ships: The Definitional Controversy and Enforcement of Genuine Link, 16 INT'L LAW. 301, 301 (1982).

24. See supra note 21 .

25. The United States signed and ratified the first convention discussing the genuine link, the 1958 Convention on the High Seas, on April 12, 1961. 1958 Convention, supra note 21.

26. 1986 Convention, supra note 21.

27. 1958 Convention, supra note 21.

28. McConnell, “... Darkening Confusion Mounted Upon Darkening Confusion": The Search for the Elusive Genuine Link, 16 J. MA.R. L. \& CoM. 365, 370-78 (1985).

29. Id. at 373.

30. B. BoczeK, supra note 18 , at 2 ('Functionally, a 'flag of convenience' can be defined as the flag of any country allowing the registration of foreign-owned and foreign-controlled vessels under conditions that for whatever the reasons, are convenient and opportune for the persons who are registering the vessels.") The "flight" of vessels from their registry to the flag of convenience states continues to pose substantial concern for the traditional maritime states because it removes substantial nunibers of vessels and, consequently, revenues and wartime bottom capacity, from the reach of the traditional maritine states. Vessel owners from the traditional maritime states often prefer to use the flag of convenience registries because of the relatively simpler and less expensive registry processes, tax breaks, and cheaper labor. Id. at 26-63. See also FirST REPORT OF THE COMMISSION on Merchant Marine and Defense: Findings of Fact and Conclusions 30 (Sept. 30, 1987); Comnent, supra note 18, at 221-25. 
During the negotiations in the 1958 Convention, the established inaritime states together with international seafarer groups sought strict vessel registration requireinents-a "genuine link" between vessels and the state of registration. ${ }^{31}$ Two major concerns motivated the push to codify a strict genuine link requirement. First, the inaritime states saw the genuine link as a ineans of imposing substantive burdens on all flagging states, thus reducing the convenience and econoiny of flag of convenience regimes and lessening their competitive threat. ${ }^{32}$ Second, various groups felt that stricter supervision of vessel conditions by the registering state would eliminate substandard vessels detrimentally affecting labor, safety, and environinental conditions at sea. ${ }^{33}$ The flag of convenience nations resisted the restrictions, claiming that strict requirements infringed upon a state's sovereign right to grant its flag at its own discretion..$^{34}$

The compromise that resulted required: (1) that "[e]ach State shall fix the conditions for the grant of its nationality to ships, for the registration . . . and for the right to fly its flag;"35 (2) that a genuine link inust exist; and (3) "in particular, [that] the State must effectively exercise its jurisdiction and control in the administrative, technical and social inatters over ships flying its flag." 36 The language of the 1958 Convention, by joining the genuine link and the required exercise of effective jurisdiction and control, at least imphied that fulfillment of the latter alone would satisfy the genuine link requirement. ${ }^{37}$ It left, however, the determination of the details to the discretion of each state, requiring only that the

31. See McConnell, supra note 28, at 368-70.

32. See Law of the Sea Conventions, S. Exec. Rep. No. 5, 86th Cong., 2d Sess. _ (1960), reprinted in 106 CONG. REc. 11,189, 11,190 (1960) [hereinafter EXECUTIVE REPORT] ("Some States, which felt their flag vessels were at a competitive disadvantage with vessels sailing under the flags of other States, such as Panama and Liberia, were anxious to adopt a definition which States like Panama and Liberia could not meet."); B. BoczEK, supra note 18, at 81-86; McConnell, supra note 28 , at $364-70$.

33. See McConnell, supra note 28 , at $369-70$.

34. B. BoczEK, supra note 18 , at $256-59$.

35. 1958 Convention, supra note 21 , art. 5 , para. 1.

36. Article 5 provides in full:

1. Each State shall fix the conditions for the grant of its nationality to ships, for the registration of ships in its territory, and for the right to fly its flag. Ships have the nationality of the State whose fiag they are entitled to fly. There must exist a genuine link between the State and the ship; in particular, the State must effectively exercise its jurisdiction and control in administrative, technical and social matters over ships flying its flag.

2. Each State shall issue to ships to which it has granted the right to fly its flag documents to that effect.

Id.

37. See Burke, Changes Made in the Rules of Navigation and Maritime Trade by the 1982 Convention on the Law of the Sea, 1986 LAw OF THE SEA INSTITUTE WORKSHOP 662, 663 (1986). 
registering states establish the conditions necessary for flagging and exercise effective jurisdiction and control once the flagging was completed.

The United States supported the flag of convenience states' efforts to define tlie genuine link requirenent as broadly and witl as few concrete requirements as possible. ${ }^{38}$ This renrains the United States' position. At the tinie of the 1958 Convention, the Umited States was, and still is, a participant in flag of convenience regimes. ${ }^{39}$ Both the United States and the flag of convenience states eventually agreed to the convention because the indeterminate language permitted them to maintam their registration systeins witliout mucli cliange. 40

2. The 1982 Third United Nations Convention on the Law of the Sea. The vagueness of the terms and uncertainty about application of the 1958 Convention did little to control the trend toward flag of convenience registry: use of the flag of convenience registries has increased by one-third since 1958.41 The next opportunity to address tlie flagging issue on a worldwide basis came at the Third United Nations Convention on the Law of the Sea (UNCLOS). ${ }^{42}$ Between the conclusion of the First Convention in 1958 and the commencement of the Third Convention in 1973, worldwide support for external control of vessels furtlier coalesced at the pronipting of labor movements and environmentalists who generally regarded flag of convenience vessels as substandard and therefore dangerous to their crews and the environment. ${ }^{43}$

The 1982 UNCLOS provisions moved away from suggesting a direct relationship between the genuine link and effective forms of jurisdiction and control. The article concerning the grant of nationality to a ship required only the existence of a genuine link, altlough again witliout defining its content. ${ }^{44}$ Further duties of the registering state were not connected with the genuine link requirenent but instead were moved to a

\footnotetext{
38. See B. Boczek, supra note 18 , at $248,256,273,285$.

39. Id. at 285 .

40. Id. at 259.

41. Burke, supra note 37 , at 663-64.

42. UNCLOS, supra note 21.

43. McConnell, supra note 28, at 378-79; N. SiNGH, supra note 16, at 8-13; Note, Promulgation and Enforcement of Minimum Standards for Foreign Flag Ships, 6 BROOKLYN J. INT'L L. 54, 54 n.1
} (1980).

44. Article 91, entitled "Nationality of Ships," provides:

1. Every State shall fix the conditions for the grant of its nationality to ships, for the registration of ships in its territory, and for the right to fiy its flag. Ships have the nationality of the State whose flag they are entitled to fly. There must exist a genuine link between the State and the ship.

2. Every State shall issue to ships to which it has granted the right to fly its flag documents to that effect.

UNCLOS, supra note 21, art. 91. 
separate article. ${ }^{45}$ The separate article contained an expanded list of duties the registering state had to undertake to ensure tliat vessels met certain international standards set out in otleer, more specialized conventions. ${ }^{46}$ Although the provision obligated the state to fulfill more coinpreliensive tasks than did the 1958 Convention, UNCLOS nonetleless failed to include, due to disagreeinent, the specific details of the genuine link that would have required mandatory national ownership and crew. The move reflected the shift from an empliasis on the role of the state to an empliasis on the quality of the vessel, thereby avoiding the difficult question of interfering in matters traditionally under the sole control of a state while at the same time addressing the problein of substandard vessels. ${ }^{47}$

3. The 1986 United Nations Conference on Conditions for Registration of Ships. United Nations Conference on Trade and Development's (UNCTAD's) studies and resolutions noting the deleterious effects of flag of convenience registries on international shipping resulted in a convention in 1986 to establish conditions for the registration of vessels. ${ }^{48}$ In particular, a 1977 report by the UNCTAD Secretariat reported that most

45. Id. art. 94 (entitled "Duties of the Flag State").

46. Article 94 lists the measures states must undertake to ensure that vessels are properly registered, manned and inspected. In addition, it permits states to report substandard vessels to the flag state, which then has a duty to investigate the vessel and take whatever remedial action is necessary. Id. art. 94, para. 5 .

47. See McConnell, supra note 28, at 382-83 ("The shift in the strategy of the traditional maritime states and organized labour from direct regulation of registration in the 1950 s, which proved politically and legally unacceptable, to indirect regulation through international standards may have succeeded in its objective [of eliminating the open registry system or sone of their commercial advantages].").

48. 1986 Convention, supra note 21 ; see, e.g., Resolution Adopted by the Committee on Shipping at its Third Special Session, Res. 43 (S-II) (Open Registry Fleets) at 2, U.N. Doc. TD/B/AC.34/2 Annex I (1982) (resolution in Annex I calling for: (1) a gradual conversion of open registries into normal registries by a process of tightening conditions of registration so that registering countries will be able to identify the owners of the vessels and make them accountable; and (2) convening a new conference). One colnmittee report noted that "[i]n the econounic context, the question which called for consideration was whether a country could properly be regarded as having a genuine link if it did not have an equitable participation in the benefits accruing from the operation of vescels [sic] registered under its flag." U.N. Conf. on Trade \& Dev.: Report of the Ad Hoc Intergovernmental Working Group on the Economic Consequences of the Existence or Lack of a Genuine Link Between Vessel and Flag of Registry, 9 UNCTAD C. at 4, U.N. Doc. TD/B/C.4/177 (1978). The resolution accompanying the report concluded that "[t]he expansion of open-registry fleets has adversely affected the development and competitiveness of fleets of countries which do not offer open-registry facilities, including those of developing countries." U.N. Conf. on Trade \& Dev.: Resolution Adopted by the Ad Hoc Intergovernmental Working Group at Its Fifth (Closing) Meeting on 10 February 1978, 9 UNCTAD C. 4 Aunex at 1, U.N. Doc. TD/B/C.4/AC.1/3 (1978). The resolution went on to state that " $\mathrm{t}] \mathrm{h}$ he following eleinents are normally relevant when establishing whether a genuine link exists between a vessel and its country of registry: (i) the inerchant fleet contributes to the national economy of the country; (ii) revenues and expenditures of shipping, as well as purchases and 
governments acceded that the genuine link standard incorporated several distinct, though uncodified, requirements, including national ownership, manning and management. ${ }^{49}$ The 1986 Convention sought to define these inissing qualities of the genuine link and to establish "the key economic links between a ship and the flag state that are often missing in practice." 50

By specifying the percentages of the owners, crews and inanagement that must be nationals of the flag state, ${ }^{51}$ the 1986 Convention went much further toward achieving a national and an economic link between the vessel and its state than either of its predecessor conventions. Close inspection of the language, ${ }^{52}$ however, indicates that the vague wording in the crucial articles covering manning, ownership and manageinent, and allowances for coinpliance according to domestic law rather than international law, leaves sufficient flexibility in the provisions to accoinmodate the current practices of the flag of convenience states. ${ }^{53}$ An even inore basic deficiency in UNCTAD's atteinpt to achieve uniformity in vessel standards is the convention's preainble's recognition of the continued right of each state, ultimately, to estabhish its own conditions for the granting of its flag. ${ }^{54}$

\section{B. Domestic Standards for Reflagging.}

Because the United States is not a party to either UNCLOS or the

sales of vessels, are treated in the national balance-of-payments accounts; (iii) the employment of nationals on vessels; [and] (iv) the beneficial ownership of the vessel ...." Id.

49. Economic Consequences of the Existence or Lack of a Genuine Link Between Vessel and Flag of Registry: Report by the UNCTAD Secretariat, 8 UNCTAD C. 4 Corr. at 9-11, U.N. Doc. TD/B/ C.4/168/Corr.1 (1977). The genuine link was generally considered to involve a combination of factors: (1) the fact of registration; (2) a substantial share of beneficial ownership by nationals of the registering state; (3) the principal place of business of the beneficial owners in the registering state; (4) the principal officers of the owning entity should be nationals of the registering state; and (5) national legislation and administering bodies to implement legislation controlling the administrative, social, technical, safety, and environmental matters of the vessels. Id. at 20-21.

50. UNCTAD Information Unit, UNITED Nations Convention on Conditions for REGISTRATION OF SHIPS ADOPTED at 1, U.N. Doc. TAD/INF/1770 (1986).

51. 1986 Convention, supra note 21, arts. 9-11.

52. For discussions of the convention provisions, see Marston, The UN Convention on Registration of Ships, 20 J. WorLd TRADE L. 575 (1986); McConnell, "Business as Usual": An Evaluation of the 1986 United Nations Convention Conditions for Registration of Ships, 18 J. MAR. L. \& CoM. 435 (1987); Sturmey, The United Nations Convention on Conditions for Registration of Ships, 1987 LLOYD'S MAR. \& COM. L.Q. 97.

53. McConnell, supra note 52, at 449.

54. The Prcamble provides, "Reaffirming, without prejudice to this Convention, that each State shall fix the conditions for the grant of its nationality to ships, for the registration of ships in its territory and for the right to fly its flag." 1986 Convention, supra note 21, preamble. 
1986 Convention on the Conditions for the Registration of Ships, ${ }^{55}$ the 1958 Convention standards apply to the United States' reflagging of the Kuwaiti tankers. ${ }^{56}$ Title 46, chapter 121 of the United States Code, governing the documentation of vessels, codifies the doniestic implenientation of the 1958 Convention. ${ }^{57}$ The Code requires that the tankers be: (1) properly constructed and inspected by the United States Coast Guard, (2) manned by the appropriate number of United States crew and officers, and (3) documented as belonging to a United States citizen. ${ }^{58}$

\section{ANALYSIS OF THE REFLAGGING}

\section{A. Meeting the Technical Requirements.}

The United States' reflagging effort was criticized almost immediately as transparent, conveying " 'temporary' cellophane flags for extension of the use of force." 59 The State Department Legal Adviser responded to such criticisn by arguing that the apphication of American statutory procedures constituted a sufficient genuine link to fulfill the requirements of the 1958 Convention. ${ }^{60}$ He noted that the vessels coniply with the vessel documentation laws of the United States, are subject to United States laws and jurisdiction, meet United States requirements for ownership, manning, and safety, are subject to United States tax and corporation laws, and are available to the government for the Military Sealift Command. ${ }^{61}$

55. For the United States' decision not to sign UNCLOS, see 2 PUB. PAPERS 911-12 (1982). For a discussion of the Reagan administration's position, see Malone, Who Needs the Sea Treaty?, 54 FOREIGN POL'y 44 (1984). For a general discussion of the background of the decision not to sign, see Larson, The Reagan Rejection of the U.N. Convention, 14 OCEAN DEV. \& INT'L L. 337 (1985). As of August 31, 1987, the United States had not signed the 1986 Convention on Conditions for Registration of Ships. See 1986 Convention, supra note 21.

56. Sofaer, Complied With U.S. Law, N.Y. Times, Aug. 16, 1987, at E24, col. 5 (letter to editor from State Department's Legal Adviser). The United States accepted the 1958 Convention on the High Seas on April 12, 1961. 1958 Convention, supra note 21.

57. See 46 U.S.C.A. $\S \S 12,101-12,122$ (West Supp. 1988). For general descriptions of the recodified United States vessel documentation laws see Drzal \& Carnilla, Documentation of Vessels: The Fog Lifts, 13 J. MAR. L. \& CoM. 261 (1982); Comment, The Vessel Documentation Act of 1980, 7 Mar. LAw. 303 (1982).

58. Staff of House of Rep. CoMm. ON MERchant Marine AND Fisheries, 100Th CONG.,

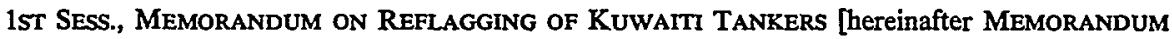
ON REFLAGGING], reprinted in Oversight on the Reflagging of Kuwaiti Tankers: Hearings Before the House Comm. on Merchant Marine and Fisheries, 100th Cong., 1st Sess. 124, 126 (1987) [hereinafter Hearings] (executive summary of Requirements, Processes and Actions in Kuwaiti Reflagging).

59. Paust, Letters to the Editor, N.Y. Times, July 26, 1987, at E26, col. 3.

60. Sofaer, Letters to the Editor, N.Y. Times, Aug. 16, 1987, at E24, col. 5 ,

61. Id. 
1. Meeting the International Standard. Under a literal interpretation of the three conventions' requirenents, the reflagging meets the standards set forth. Although the United States is not a party to the 1986 Convention, current United States vessel documentation requirements would qualify under 1986 standards because the critical provisions permit each state to implement the 1986 Convention according to its own law.62 The reflagging meets the ownership ${ }^{63}$ and managenient provisions, ${ }^{64}$ but does not meet the national crew requirement. ${ }^{65}$ Under the terms of the 1986 Convention, however, it need only meet the ownership or n1anning requirements, not both. ${ }^{66}$

The United States reflagging also meets the 1958 Convention criteria because the United States has established the conditions necessary for the registration of vessels under its domestic law. The United States has the authority to regulate the administrative, technical and social matters of the vessels, and it exercises effective jurisdiction and control over the vessels. ${ }^{67}$ As nothing more is hiterally required by the language of the

62. See supra note 53 and accompanying text.

63. Article 8, paragraph 2 provides that the flag state, in its laws and regulations, shall include appropriate provisions for participation by that State or its nationals as owners of ships flying its flag or in the ov/nership of such ships and for the level of such participation. These laws and regulations should be sufficient to permit the flag State to exercise effectively its jurisdiction and control over ships flying its flag.

1986 Convention, supra note 21, art. 8, para. 2.

Chesapeake Shipping, Inc. is, under the laws of the United States, a U.S. corporation and is owner of the vessels. "Owner" is defined simply as the person on record as owning the vessel; the article does not require equity ownership by nationals. Id. art. 2 . Thus, it would appear that Chesapeake Shipping, Inc., a wholly-owned Kuwaiti company, would qualify because it has met the requirements of the flag state's laws for establishing ownership.

64. The 1986 Convention requires that, "before entering a ship in its register of ships, [the registering State] shall ensure that the shipowning company or a subsidiary shipowning company is established and/or has its principal place of business within its territory in accordance with its laws and regulations." Id. art. 10.

Further, the ship's management persons are "duly empowered to act on the shipowner's behalf and account," and are available for any legal process. $I d$. art. 10, para. 2 . The flag state must ensure that the responsible managers of the vessels "are in a position to meet the financial obligations that may arise from the operation of such a ship to cover risks which are nonnally insured in international maritime transportation in respect of damage to third parties." Id.

Chesapeake Shipping, Inc. satisfles the requirements because it has a subsidiary in the United States and ensures that the company is subject to service of legal process in the United States.

65. Article 9 provides that a state of registration "shall observe the principle that a satisfactory part of the complement consisting of officers and crew of ships flying its flag be nationals or persons domiciled or lawfully in permanent residence in that State." Id. art. 9.

As the master of each tanker is the only U.S. citizen in the crew, the reflagged tankers would clearly fail this part of the test, because although the Convention provides no standard for "satisfactory," leaving it to the flag state's discretion, no one could legitimately argue that only one of the crew for a supertanker is a "satisfactory" number.

66. Article 7 allows signatories to the Convention to select to comply with either the ownership or the manning provisions or both. Id. art. 7.

67. See infra notes 69-83 and accompanying text. 
1958 Convention in assuring that a genuine link exists, the link, ipso facto, is established. To the extent that the 1958 Convention sought to impose a certain public order on the oceans ${ }^{68}$ by establishing a system to locate those responsible for vessels and ensuring that all vessels meet certain community standards for safety, the Kuwaiti reflagging meets those needs.

2. Meeting the Domestic Standards. The domestic procedures applied to reflag the Kuwaiti tankers were based on preexisting policy and practice. No new laws were written specifically for the occasion; none were waived except by statutory authority; no extraordinary procedures were used. ${ }^{69}$ Because the Kuwaiti tankers met all necessary statutory requirements or conditions for waivers, the reflagging, under domestic law, was technically proper.

The Coast Guard conducted the inspection in Kuwait.70 As part of the permissible inspection procedures, the Departinent of Defense requested a one-year waiver from comphance with those United States requirements that exceed requirements set by certain international safety conventions. ${ }^{71}$ The Department of Defense request was premised on preexisting national security waivers provided in the Code. ${ }^{72}$

United States-flagged vessels normally must carry a full complement of Umited States officers and at least 75\% United States crew upon leaving a Umited States port. ${ }^{73}$ If, however, a vessel is in a foreign port and is

68. N. SiNGH, supra note 16 , at 3 .

69. MEMORANDUM ON ReflaGging, supra note 58, at 5, reprinted in Hearings, supra note 58, at 132 (view maintained by Coast Guard).

70. See id. at i (Executive Summary), reprinted in Hearings, supra note 58, at 126; $c f$. UNITED States General accounting Office, Additional Costs to Government: Reflagging Kuwaiti Shits and Protecting Them in the Persian Gulf 2 (1987). The GaO report notes that, in accordance with its usual procedures for performing overseas inspections, 46 U.S.C.A. $\S 3317$ (b) (West Supp. 1987), the Coast Guard billed the Kuwaiti shipping company the $\$ 19,000$ necessary to complete the inspection. Id.

71. Memorandum on Reflagging, supra note 58, at 5, reprinted in Hearings, supra note 58, at 132. The Defense Department request is authorized by the Act of December 27, 1950, 46 U.S.C. app. ch. 1 note (Snpp. III 1985). The request waives compliance with those vessel inspection and navigation laws that exceed the standards set by the following international conventions to which the United States is a party: the International Convention for the Safety of Life at Sea (SOLAS), opened for signature June 17, 1960, 16 U.S.T. 185, T.I.A.S. No. 5780, 536 U.N.T.S. 27, opened for signature Nov. 1, 1974, 32 U.S.T. 47, T.I.A.S. No. 9700; the Convention on the Prevention of Marine Pollution by Dumping of Wastes and Other Matters (MARPOL), opened for signature Dec. 29, 1972, 26 U.S.T. 2403, T.I.A.S. No. 8165, 1046 U.N.T.S. 120; and the International Convention on Load Lines, opened for signature Apr. 5, 1966, 18 U.S.T. 1857, T.I.A.S. No. 6331, 640 U.N.T.S. 133. The waivers were requested for one year, exccpt for the drydocking requirements, for which a two year waiver was requested. MEMORANDUM ON REFLAGGING, supra note 58, at 5, reprinted in Hearings, supra note 58 , at 132 .

72. Act of Deceinber 27, 1950, 46 U.S.C. app. ch. 1 note (Supp. III 1985).

73. 46 U.S.C. $\$ \S 7102,8103$ (a)-(b) (Supp. III 1985). 
deprived of her crew, ahen replacements are sufficient until the vessel returns to a United States port and can secure Umited States replacements. ${ }^{74}$ This exemption does not apply to the master; the master commanding a United States vessel must always be a United States citizen. ${ }^{75}$ The United States Coast Guard, over the objection of several seamen's groups, ${ }^{76}$ considered the Kuwaiti tankers as falling withm the ambit of the exemption.77 Because the Kuwaiti tankers are not departing from or calling at a Umited States port, the $75 \%$ Umited States crew and $100 \%$ United States officer requirements were deemed mapplicable. ${ }^{78}$ The tankers are inanned by non-U.S. citizens and U.S. masters; the Kuwaitis agreed to replace the Soviet-bloc sailors on four of its tankers with Filipino crew and European or Arab officers. ${ }^{79}$

United States ownership requirements are satisfied if a vessel is owned by a Umited States citizen or corporation..$^{80}$ Corporate citizenship requirements are satisfied if: (1) the corporation is imcorporated under the laws of the United States or any state thereof; (2) the president or other chief executive officer and the chairman of the board of directors are United States citizens; and (3) the number of foreign directors is less than the number necessary to constitute a quorum. ${ }^{81}$ The reflagged tankers are owned by the Delaware corporation, Chesapeake Shipping, Inc., which was formed under Delaware law on May 15, 1987.82 The corporation assumed ownership and operation of the eleven reflagged tankers, previously owned by the Kuwait Oil Tanker Company; the corporation then chartered the tankers back to the Kuwaiti company. ${ }^{83}$ Because

74. Id. § 8103(e).

75. Id. $\S \S 8103(\mathrm{e}), 7102,8103(\mathrm{a})$.

76. Various maritime organizations representing seamen, masters and pilots, and radio officers testified at the U.S. House of Representatives Merchant Marine and Fisheries Committee's hearing on the reflagging on June 18,1987, objecting to the manning arrangements for the Kuwaiti vessels that required only a U.S. master on the vessels rather than the usual $100 \%$ U.S. officer and $75 \%$ U.S. crew arrangement. See Hearings, supra note 58, at 109-115, 118-23, 175-80, 227-31 (statement of representatives of the Seafarers International Umion of North America, International Organization of Masters, Mates and Pilots, and AFJ_CIO Maritime Committec/National Maritime Umion).

77. See id. at 77 (statement of Rear Admiral John W. Kime, U.S. Coast Guard, Chief, Office of Marine Safety, Security and Environinental Protection).

78. Memorandum ON Reflagging, supra note 58, at 10, reprinted in Hearings, supra note 58 , at 137.

79. Id.

80. 46 U.S.C.A. § 12,102(a) (West Supp. 1987).

81. Id. \& 12,102(a)(4).

82. Hearings, supra note 58, at 104 (statement of Mark P. Schlefer, counsel to Chesapeake Shipping, Inc.).

83. All of the issued and outstanding shares of Chesapeake Shipping, Inc. are owned by the Kuwait Oil Tanker Company, a wholly-owned subsidiary of the Kuwait Petroleum Corporation, which is owned by the Kuwait government. Delaware Firm Is New Home of Kuwaiti Ships, Wash. Post, July 5, 1987, at A21 [hereinafter Delaware Firm]. The President/Chief Executive Officer, the 
neither United States nor international law requires equity ownership, Chesapeake Shipping, Inc., with its Delaware registration, American president and chief executive officer, and a najority of United States citizens on its board of directors, meets the domestic statutory requirements for United States corporate ownership even though the corporation and tankers are still essentially owned by the Kuwaiti government.

\section{B. Meeting the Spirit of the Law.}

Although the reflagging meets the technical requirements, whether the reflagging meets the spirit of the genuine link requirement is another matter. Although the United States is not bound by it, the 1986 Convention indicates a trend towards a good faith national link between vessels and states. ${ }^{84}$ The reflagging does not ineet this intention; there is very little about the tankers that is American. Neither their trne owners, their management, nor their crew are by najority Umited States citizens.

The United States reflagging defeats the purposes of the 1986 Convention inasmuch as the 1986 Convention seeks to reduce the opportunites for unilateral flagging decisions and to eliminate the perceived unfairness of permissive links by imposing some degree of uniformity on vessel registration. Although the 1986 Convention addressed itself to the perceived abuses arising fron flag of convenience practices, that does not make the 1986 Convention any less applicable to politically expedient refiaggings. It is expediency that the 1986 Convention imtended to eliminate by basing vessel registration on inore solid ties.

The non-genuine character of the link arises fron the transparent manipulation of statutes designed to address the peculiarities of maritime commerce to serve immediate political goals. The inove may have been a savvy political one, as it is based on the presumptive nature of the flagonce attributed it cannot be questioned ${ }^{85}$-but that does not niake the affair any less transparent.

Vice-President/Assistant Secretary, the Vice-President/Corporate Secretary and two more Assistant Secretaries of Chesapeake Shipping, Inc. are Umited States citizens. The remainder of the officers of the corporation inclnde one Kuwaiti citizen, one United Kingdom citizen and one Jordanian citizen. Hearings, supra note 58, at 104-05 (statement of Mark P. Schlefer, counsel to Chesepeake Shipping, Inc.).

In May, when it became apparent that the vessels required a U.S. owner to qualify for registration, the officers of the Sante Fe International Corporation, a Kuwait Petroleum Corporation-owned company, created Chesapeake Shipping, Inc. to take title to the 11 tankers. The company is represented by a registered agent in Delaware, its only place of business in the United States, and has assets of $\$ 350$ million, the value of the tankers. Delaware Firm, supra, at A21.

84. See supra notes 48-51 and accompanying text.

85. See M. McDougal \& W. Burke, The Public Order of the Oceans 1011-12 (2d ed. 1987); see also EXECUTIVE REPORT, supra note 32, at 11,190 (Senate ratified of the 1958 Law of the Sea Convention with the understanding that only the flag state can question the national character of 
There was no legal impediment to escorting and protecting the tankers while they were flying the Kuwaiti flag. ${ }^{86}$ The Umited States could have worked out a collective defense agreenent that would have afforded American protection to Kuwaiti tankers. ${ }^{87}$ There were several reasons why the United States did not do so: (1) the USSR offered to reflag several of the Kuwaiti tankers; ${ }^{88}$ (2) doinestic political opponents objected to an open-ended coinmitınent to protect friendly shipping; ${ }^{89}$ and (3) it was presuined, based on previous experience in the war, that the Iranians would not attack tankers flying the American flag. ${ }^{90}$

Whether the United States chose the most appropriate course in reflagging the tankers is a question left to time and the historians. Because the reflagging and escort request was generated by the Kuwaiti government at its own imitiative, the reflagging was at least not a unilateral excuse for a buildup of naval forces in the Gulf. It was, however, an opportunity to strengthen the link between legal justifications and the foreign policy need for a presence in the Gulf - an opportunity of which the Reagan adininistration took full advantage.

a ship); 46 U.S.C.A. $\$ 12,104$ (West Supp. 1987) ("A certificate of documentation is-(1) conclusive evidence of nationality for international purposes . ...").

86. M. McDougal \& W. BuRke, supra note 85, at 1065-66 (quoting R. Rienow, The TesT OF THE NATIONALITY OF A MERCHANT VESSEL 104-05 (1937)) (A State inay defend the vessels of allother State "so long as [the escort] does not confilict with the control which the State to which the vessel legally belongs is, under international law, permitted to effect and does, in fact effect.").

87. This is the same idea at work in collective defense arrangements such as the NATO alhalice. Countries agree to render mutual assistance if their territory is attacked and can do the same with respect to vessels. Neither domestic nor international law limits protection to American vessels only. Indeed, Defense Secretary Weinberger, testifying before the Senate Foreign Relations Committee, said that the United States, following "practices accepted by all civilized countries," would come to the aid of ships attacked in the Gulf even if they did not fiy the American fiag. Healy, Weinberger Outlines Limits of Policy in Gulf; Says U.S. Will Help Any Vessel Under Attack but He Is Ambiguous on Degree of Protection, L.A. Times, Oct. 24, 1987, pt. 1, at 4, col. 1. President Reagan cast the U.S. role as proteeting "neutral-nation shipping in international waters." Id. In practice, however, that has not been the case; the U.S. naval escorts have refused to come to the aid of vessels not flying the U.S. flag. Iranian Frigate Attacks Greek Tanker in Gulf, Wash. Post, Dec. 16, 1987, at A41, col. 2-3 (U.S. destroyer Chandler took no action in defense of Greek tanker attacked by Iranians "because its rules of engagement prohibit defense of a non-American ship.").

88. See C. Weinberger, supra note 3 , at 10.

89. Indeed, several bills proposed to block the reflagging effort until the administration at least reported its plans for seeking assistance from U.S. allies im protecting the Kuwaiti tankers. See, e.g., H.R. 3039, 100th Cong., Ist Sess. (proposing to block reflagging until Kuwait allowed U.S. to base minesweepers on Kuwaiti territory), reprinted in Hearings Before the Comm. on Merchant Marine and Fisheries on Oversight on the Reflagging of Kuwaiti Tankers and U.S. Naval Escorts for Kuwaiti Tankers-H.R. 3039, 100th Cong., 1st Sess. 343-45 (1987); Hill Demonstrates Its Unease Over Policy in the Persian Gulf, 45 CoNG. Q. 1169,1169 (1987) (discussing an appropriations bill anendment to require a report on U.S. allies' assistance before reflagging could commence).

90. See What Are the Targets Iran Likes to Attack, 133 CONG. REC. E2570, E2572 (daily ed. June 24, 1987) (Rep. Aspin stated that "[t]he Iranians have not . . . ever struck an American vessel."). 
The United States has fit the reflagging under the international standard of the genuine link. As discussed above, it has done so within the letter if not within the spirit of the law. The reflagging does not fit within the spirit of the law because of the basic incongruity arising from assessing a political action against a standard directed to the peculiarities of the nerchant shippinig industry. The standard to nieasure the assertion of sovereign rights in this case is not that of the genuine link but that of other, broader principles of niternational law-those of protecting the freedoin of the seas and of enforcing rights under international conventions.

\section{The United States Presence in the Persian Gulf}

If the genuineness of the link between the tankers and the United States does not provide complete legal support for United States actions in the Persian Gulf, then other, broader principles of international law nust justify the actions. Urited States actions in the Persian Gulf address intrusions on a crucial international freedon1-the freedoin of navigation. ${ }^{91}$ Both Iran and Iraq have impeded that freedom through air attacks on merchant vessels and by sowing free-floating mines in shipping lanes. The presence of the United States and Allied navies in the Persian Gulf is a legally justifiable effort to deter illegal actions and assert custoniary principles governing the right of vessels to transit the oceans during peacetime and times of conflict.

91. "This country, throughout its existence has stood for freedom of the seas, a principle whose breach has precipitated wars among nations." United States v. California, 332 U.S. 19, 34 (1947). For a discussion of the development of the principle of the freedom of the seas, see $4 \mathrm{M}$. WHITEMAN, DIGEST OF INTERNATIONAL LAW 501-02 (1965). One of the more modern examples of protecting the freedom of the seas by the display or actual use of force is the British protest of the Albanian attempt to close the Corfu Channel to warships by sending British warships through the channel. After two of the warships struck mines, the British brought the case before the International Court of Justice, which decided-based on state practice and conventional law-in favor of the right of ships and warships to pass innocently through the territorial waters of a state. Corfu Channel (Gr. Brit. v. Alb.), 1949 I.C.J. 4, 36 (Apr. 9, 1949). The North Sea Fisheries cases, adjudicated in the International Court of Justice between the United Kingdom, Germany, and Iceland in 1973, imvolved the right of Iceland to claim a twelve-mile territorial sea off its coasts and exclude foreign fishing vessels from it. The opposing contentions of the parties led to gunfights between fishing vessels and later to skirmishes between warships when the Umited Kingdom sent navy ships to accompany its fishing vessels within Iceland's twelve-mile limit. Fisheries Jurisdiction (U.K. v. Ice.), 1973 I.C.J. 3 (Feb. 2, 1973). A more recent example of protesting unsubstantiated clains of high seas oceurred between the United States and Libya in the Gulf of Sidra on August 19, 1981, when the United States sent sone of its warships on naval nuaneuvers across the line that Libya clainied inarked its internal waters. (Colonel Qhadaffi called it the "Line of Dcath.") See Ratner, The Gulf of Sidra Incident of 1981: A Study of the Lawfulness of Peacetime Aerial Engagements, 10 YALE J. INT'L L. 59, 64-66 (1984) (discussing the legitimacy of U.S. naval maneuvers in the Gulf of Sidra). 


\section{A. Freedom of the Seas.}

The right the United States seeks to protect in the Persian Gulf is the well-established right of vessels to transit the seas. Since the seventeenth century, when Grotius pubhished his fainous treatise on the freedoms of the seas, ${ }^{92}$ states have developed and refined customary laws permitting all vessels to travel the high seas with minimal interference except from the state whose flag they fly. The customary laws and practices were finally codified in two conventions on the law of the sea-the 1958 Convention ${ }^{93}$ and the 1982 Convention (UNCLOS). ${ }^{94}$

The latest, UNCLOS, is the inost comprehensive and ambitious, covering a wide variety of peaceful uses of the seas, mcluding navigation. ${ }^{95}$ The absolute right of vessels to transit the seas is now somewhat limited by claims of coastal states to imcreasing areas of territory and authority 96 and by the modern needs to mamtain environmental and navigational safety. UNCLOS balances the need for free navigation with coastal states' rights to protect and control the areas off their shores by codifying a regime that subjects vessels to only a minimum prescribed set of regulations as long as vessels are navigating expeditiously through the seas. ${ }^{97}$

The United States and Iran agree on the basic freedoms of navigation as codified in the 1958 Conventions and UNCLOS. 98 When the convoys are moving through the high seas or exclusive economic zones of

92. The treatise was entitled The Freedom of the Seas. See 1 D. O'CONNELL, The INTERNATIONAL LAW OF THE SEA 9-18 (1982).

93. 1958 Convention, supra note 21.

94. UNCLOS, supra note 21.

95. See generally id. art. 2-44 (setting out the framework of the rights and obligations of vessels and coastal states with respect to, among other issues, navigation through the various zones of the ocean established in the convention).

96. UNCLOS codified a regime that permitted states to claim up to 200 miles off their coasts as exclusive economic zones, zones in which the coastal state has sole authority to regulate the economic exploitation of the resources. Id. arts. 55-58. UNCLOS also permitted coastal states more control particularly over the environmental conditions of the ships than had previous conventions. See, e.g., id. arts. 218,220 (giving port states and coastal states, respectively, power to institute proceedings to enforce international environmental laws agaimst foreigu vessels in their waters). For a discussion of the trend of increasing claims, see Henkin, Politics and the Changing Law of the Sea, 89 PoL. ScI. Q. 46, 49-50, 55-60 (1974).

97. See, e.g., UNCLOS, supra note 21 , arts. 17-19 (prohibiting coastal state interference with a vessel while it is passing through the state's territorial waters unless the vessel is not moving on an uniterrupted course).

98. The United States has tacitly agreed to accept the UNCLOS navigational provisions; Iran explicitly agreed to be bound by them. In a statement on U.S. policy, President Reagan, while noting that the United States had deehined to sign UNCLOS, stated nonetheless

First, the United States is preparel to accept and act in accordance with the balance of interests relating to traditional uses of the oceans-such as navigation and overfight. In this respect, the United States will rccognize the rights of other states $m$ the waters off their 
the Persian Gulf they are entitled, as a right, to unimpeded passage. 99 The United States and Iran disagree, however, on the nature of the right of passage through international straits such as the Strait of Hormuz. ${ }^{100}$ That disagreement is not limited to the United States' and Iran's claims in the Strait of Hormuz, but extends to a broader general disagreement

coasts, as reflected in the Convention, so long as the tights and freedoms of the United States and others under international law are recognized by snch coastal states.

Statenrent on United States Oceans Policy, 1 PuB. PAPERs 378, 379 (1983) [hereinafter EEZ Proclaunations]; see also RestatemENT (REviSED) of THE FoREIGN RELATIONS LAW of THE UNITED STATES pt. V, introductory note 55 (Tent. Draft No. 3 1982). The tacit agreenent by the United States, accompanied by consistent practice of abiding by the terms of the Convention, expresses a clear intention to be bound by, and a duty to try in good faith to comply with, the navigational provisions. The Iranian government signed UNCLOS, but it has not yet ratified it. See U.N., THE LAW of THE SEA: UNITEd NATIONS CoNvention ON THE LAW of THE SEA at 190, U.N. Sales No. E.83.V.5 (1983); for the text of the Iranian declaration at the signing, see OFFICE OF THE SPECIAL REPRESENTATIVE OF THE SECRETARY-GENERAL FOR THE LAW OF THE SEA, 5 LAW OF THE SEA BULlETIN 13-15 (July, 1985) [heremafter LAw OF THE SEA BulLETn]. The Iranian signature imports a duty to make good faith efforts, to refrain from misusing its rights or violating the provisions of the Convention prior to ratification. See 1 L. OPPENHEIM, INTERNATIONAL LAw 909 (H. Lauterpacht 8 th ed. 1955). Thus, at least with respect to the navigational provisions of UNCLOS (omitting the straits passage provisions), the two countries agree that those are the rights to which vessels and coastal states are entitled to claim.

99. For a discussion of the use of an exclusive economic zone, see supra note 96 . High seas are those areas outside any state's control whose economic exploitation is not subject to appropriation by any one particular state. Althongh the two concepts differ with respect to the right to regulate economic exploitation, they are treated identically with regard to navigational rights. Both areas are governed by the right of freedoin of navigation. Compare UNCLOS, supra note 21, art. 58 (exclusive economic zone right to the freedom of navigation) with $i d$. art. 87 (the high seas right of the freedom of navigation). Article 90 provides for the right of navigation as follows: "Every State, whether coastal or land-locked, has the right to sail ships under its flag on the high seas." Id. art. 90.

100. When Iran signed UNCLOS, it declared that it considered that only states party to the Convention could benefit from its provisions generally and in particnlar from the special provisions concerning unimpeded passage through straits. See LAW OF THE SEA BULLETIN, supra note 98, at 14. For states not party to the Convention and as an interim nieasure until the Convention takes effect, Iran claims authority to regulate or prohibit passage of vessels if its national secnrity is threatened. See id. (current position on passage); C. MACDONALD, IRAN, SAUDI ARAB1A, AND THE LAW OF THE SEA 102-03, 107 (1980) (historic claims to regulate passage). For general backgronnd on the Iranian position with respect to the law of the sea, see A. EL-HAKIM, THE MIDDLE EASTERN STATES AND THE LAW OF THE SEA 43-79 (1979).

The United States, on the other hand, considers that all of the navigational provisions of UNCLOS reflect customary international law, thereby codifying certain state practices in which all states are entitled to participate.

First, the United States is prepared to accept and act in accordance with the balance of interests [in UNCLOS] relating to traditional uses of the oceans-such as navigation and overflight. In this respect, the Umited States will recognize the rights of other states in the waters off their coasts, as reflected in the Convention, so long as the rights and freedoins of the United States and others under international law are recognized by such coastal states. Second, the United States will exercise and assert its navigation and overflight rights $\ldots$ in a manner that is consistent with the balance of interests reflected in the convention [sic].

Statement on United States Oceans Policy, 1 PuB. PAPERs 378, 379 (1983). As UNCLOS codifies a regime of unimpeded passage through straits and the United States supports that position, there is disagreement over whether Iran can regnlate vessel passage through the Strait of Hormuz. 
over whether a customary right of unimpeded passage through straits exists outside of the conventional right codified in UNCLOS. ${ }^{101}$ The disagreement may be irrelevant, however, because vessels in the Persian Gulf can transit the Strait of Hormuz through the channel running through Oman's territorial waters, where Iran has no legitimate claim to regulate passage. The Omanis have permitted vessel traffic through their side of the strait throughout the war and have resisted Iranian imcursions into their waters. ${ }^{102}$

\section{B. Protests Under International Law.}

The real disagreement between Iran and the Umited States is not over the particulars of the navigational provisions of the law of the sea, but rather over illegal Iranian military maneuvers to impede rightful passage. Besides safety restrictions, the freedom of the seas admits of only one permissive interference-war. ${ }^{103}$ Even during wartime, however, belligerent states are not entitled to impede passage at their discretion. ${ }^{104}$ Traditional laws of war and modern principles of humanitarian law carefully define pernissible restrictions on navigation during war. ${ }^{105}$ Military nianeuvers such as the imdiscriminate mining of the Persian Gulf are illegal under either body of law. 106

States whose interests are threatened by the illegal actions are entitled to protest and seek redress. ${ }^{107}$ Paper protests are the preferred

101. See, e.g., Grunawalt, United States Policy on International Straits, 18 OCEAN DEV. \& INT'L L. 445 (1987); Harlow, UNCLOS III and Conflict Management in Straits, 15 OCEAN DEV. \& INT'L L. 197, 200 (1985); Robertson, Passage Through International Straits: $A$ Right Preserved in the Third United Nations Conference on the Law of the Sea, 20 VA. J. INT'L L. 801 (1980).

102. Amin, The Regime of International Straits: Legal Implications for The Strait of Hormuz, 12 J. MAR. L. \& COMM. 387, 397 (1981).

103. The law of the sea does not address the issue of war; the conventional and customary laws of naval warfare embody the restrictions that may be imposed on vessels during wartime. For an extended discussion of the particular provisions of the laws of naval warfare, see Tucker, The Law of War, in 2 READings IN INTERNational LAW FROM tHe Naval War College Review 1947-1977 233-46 (R. Lillich \& J. Moore eds 1980), part of series 61-62 U.S. NAVAL WAR COLLEGE INTERNATIONAL LAW STUDIES 233-46 (1980).

104. See 2 L. OPPENHEIM, INTERNATIONAL LAw $\S 175$ (H. Lauterpacht 7 th ed. 1952) (discussing legitimate means of sea warfare).

105. See generally id. at $\S \S 173-213$; Tucker, supra note 103, at 50-143, 196-354.

106. See infra notes 120-37 and accompanying text.

107. For a catalog of examples of the various causes of action based on breaches of international obligations see, I. BROWNLIE, SYSTEM OF THE LAW OF NATIONS: STATE ResponsibiLITY 60-62 (1983) [hereinafter I. BRowNLIE, STATE ResponsibiLITY]. For a discussion of the obligation to make reparations for damages arising from the illegal use of force, see I. BRownLIE, INTERNAtional LAW AND the USE OF ForCe by States 133-49 (1963). See also Note, Limited Armed Conflict Causing Physical Damage to Neutral Countries: Questions of Liability, 15 CAL. W. INT'L L.J. 161, 165-66, 168 (1985) (applying law of international responsibihity to Iran-Iraq Armed Conflict). In the present case, the Iranian actions of attacking neutral merchant vessels and mining waters constitute both breaches of customary obligations and violations of various conventions. See, 
method of protest. 108 The efficacy of contimued paper protests alone, however, is controversial. On the one hand, paper protests should be sufficient; states should not be required to take extra measures to enforce or maintain their rights. On the other hand, the liberal use of paper protests dilutes their impact so that, without some further move, the right to protect the claim matures and is lost. 109

In the Persian Gulf, where the Umited States claims to protect the rule of law and does so in a notorious maimer, it is crucial that the United States abide by the post-United Nations Charter guidelines. State practice and protests often lead to the developinent of new norms of customary international law. ${ }^{110}$ In order to lead development in a direction that strengthens, rather than weakens the rule of law, states combatting illegal practices must themselves take care not to eniploy illegal practices.

In this post-United Nations Charter period, the protection of claims through the peaceful settlement of disputes is the norm ${ }^{111}$ and should be observed by states durimg the Iran-Iraq War. The Charter prohibits the

e.g., Amerada Hess Shipping Corp. v. Argentine Republic, 830 F.2d 421, 423-24 (2d Cir. 1987) (holding that attacking neutral merchant ship on high seas outside of war exclusion zones without warning requires restitution); Military and Paramilitary Activities In and Against Nicaragua (Nicar. v. U.S.), 1986 I.C.J. 14, 112, (holding that mining waters traveled by commercial vessels without notification breaches the specific provisions of The Hague Convention No. VIII of 1907 (infra note 119 ) and the principles of humanitarian law).

108. For examples of typical diplonnatic protests, see I. BRowNLIE, STATE RESPONSIBILITY, supra note 107 , at 2426 .

109. $1 \mathrm{D}$. O'CoNNELL, supra note 95 , at $40-42$. For the principle that claims inay mature if not acted upon, see Island of Palmas (U.S. v. Neth.), Hague Ct. Rep. 2d (Scott) 83, 126-29 (Perm. Ct. Arb. 1928) (discussing the failure, over a long period of time, to substantiate territorial claims and its effect on the right to claim that territory).

110. See M. MCDOUGAL \& W. BURKE, supra note 85, at 28-35 (claimants of right include all actors in world social process); $1 \mathrm{D}$. O'CONNELL, supra note 92, at 38-49 (discussing how protests and treaties may have a far-reaching impact on customary international law); McDougal, The $H y-$ drogen Bomb Tests and the International Law of the Sea, 49 AM. J. INT'L L. 356, 356-57 (1955) (international law is a process of "continuous interaction"). See generally Gamble, The Treaty/ Custom Dichotomy: An Overview, 16 TEX. INT'L L.J. 305 (1981) (focusing on the roles of treaty and custom as sources of international law).

111. J. Stone, Legal Controls of International Conflict 300 (1959). Since 1928, when the Kellog-Briand Pact caine into force "for virtually all States in the world," condemning "recourse to war for the solution of international controversies, and renounc[ing] it as an instrument of national policy in their relations with one another," traditional war has been an unrecognized and violative concept under international law. Treaty Renouncing War as an Instrunent of National Policy, Aug. 27, 1928, art. I, 46 Stat. 2343, 2345-46, T.S. No. 796, at 3-4, 94 L.N.T.S. 57, at 63 (also known as the Kellog-Briand Pact and the Pact of Paris). The United Nations Charter confirms that policy, providing that, "[a]11 Members shall settle their international disputes by peaceful means in such a manner that international peace and secnrity, and justice, are not endangered." U.N. CHARTER, art. 2(3). Compare 2 L. OPPENHEIM, supra note 108, at 177-78 (noting the legality of recourse to war prior to the Kellog-Briand Pact) with Schindler, State of War, Belligerency, Armed Confict, in The New Humanitarian Law of Armed Conflict 3, 5 (A. Cassese ed. 1979) (discussing the negligible impact of the Kellog-Briand Pact and subsequent agreements in limiting hostilities). 
aggressive use of force and resort to war as methods of protecting a legitimate claim. ${ }^{112}$ The Charter allows force only when used in self-defense. Self-defensive force is limited to carefully circumscribed situations ${ }^{113}$-if there is any force used at all, even im protesting the most flagrant violations, the employinent of force must be defensive, rather than offensive. Despite the difficulty of relying on paper protests, states are obliged to, ${ }^{114}$ and inust work towards, compliance with Charter principles if the principles are to continue guiding state actions in response to aggressive and illegal uses of force.

In responding to the mining activities, the Umited States has atteinpted to comply with United Nations Charter guidelines. When paper protests and United Nations Security Council Resolutions ${ }^{115}$ failed, the United States and its Allies moved to more visible and active forms of protest-reflagging the Kuwaiti tankers and sweeping the Gulf to rid it of mines. The interdiction of the Iramian minelayer is the only forceful ineasure the United States or the Allies have taken in response to the extensive mining of Persian Gulf waters because it is the only instance in which clear-cut evidence of immediately threatening illegal activities justified the use of force in self-defense.

112. Article 2(4) of the United Nations Charter provides that:

[a]11 Members shall refrain in their international relations from the threat or use of force against the territorial integrity or political independence of any State, or in any other manner inconsistent with the Purposes of the United Nations.

U.N. ChARTER, art. 2(4).

113. Article 2(4) is considered to prohibit any use of force except in the limited circumstance when it is necessary for self-defense as provided in Article 51:

Nothing in the present Charter shall impair the inherent right of individual or collective self-defense if an armed attack occurs against a Member of the United Nations, until the Security Council has taken the neasures necessary to maintain international peace and security. Measures taken by Members in the exercise of this right of self-defense shall be immediately reported to the Security Council and shall not in any way affect the authority and responsibility of the Security Council under the present Charter to take at any time such action as it deems necessary in order to naintain or restore international peace and security.

Id. art. 51. States have also justified the use of force by claiming that the government under attack requested that the state intervene. For example, the United States justified the use of force in invading Grenada partly on the claim that the Governor-General of Grenada requested U.S. assistancc. See Joyner, The United States Action in Grenada: Reflections on the Lawfulness of Invasion, 78 AM. J. INT'L L. 131, 137 (1984) (noting that this claim was a "prominent legal justifieation for the Grenada action"); Schachter, In Defense of International Rules on the Use of Force, 53 U. CH1. L. REV. 113, 118 (1986) (noting that this jusitification was one of threc made by the State Department). See generally Brownlie, The United Nations Charter and the Use of Force, 1945-1985, in THE CURRENT LEGAl Regulation OF THE USE OF FORCE 500-02 (A. Cassese ed. 1986) (tracing U.S. "intervention by request" since 1945).

114. Article 2 of the United Nations Charter, which includes the duties to settle disputes through peaceful measures and to refrain from the use of force, opens with the statenient: "The Organization and its Members, in pursuit of the Purposes stated in Article 1, shall act in accordance with the following Principles." U.N. CHARTER art. 2 (emphasis added).

115. See supra note 12. 


\section{The Mining of Persian Gulf Waters.}

Mines-laid indiscriminately throughout the Gulf-have been one of the most serious impediments to safe vessel navigation during the Iran-Iraq War. Mining is restricted by both international war conventions and inodern principles of humanitarian law. ${ }^{116}$ Both bodies of law prohibit sowing free-floating, activated inines of the type deployed by the Iranians. ${ }^{117}$ Efforts to halt the illegal inining activity are limited, however, by the principles prohibiting the use of force except in those situations of necessary self-defense. ${ }^{118}$ As a result, the United States and its allies have rehed on minesweeping to frustrate the illegal activities. Only when the Umited States had absolute proof of illegal mining activities by the Iranians did it move to protect its vessels in self-defense. ${ }^{119}$ The combination of minesweeping and forceful actions, when necessary, serves notice that illegal activities will not be tolerated or accepted as part of state practice.

1. International Law on Mining. The laws governing nining derive from several different sources, including the 1907 Hague Convention No. VIII, ${ }^{120}$ customary principles, ${ }^{121}$ the Corfu Channel case ${ }^{122}$ and the

116. See infra notes $120-37$ and accompanying text.

117. Id.

118. See supra notes $112-13$ and accompanying text.

119. The international law test governing the judgment of the propriety of the use of force in self-defense, like the municipal comnion law test, comprises both objective and subjective standards. Zedalis, Preliminary Thoughts on Some Unresolved Questions Involving the Law of Anticipatory SelfDefense, 19 CASE W. RES. J. INT'L L. 129, 150-51 (1987) ("the required state of mind has both a subjective as well as an objective component"). Import of the objective, "reasonable man" standard to international evaluation is necessary to effect the policy of the justiciability of self-defense, that is, that no nation may be the final judge of its own actions. Schachter, Self-Judging Self-Defense, 19 CASE W. RES. J. INT'L L. 121, 123-27 (1987) (discussing the necessity for justiciability of states' claims of self-defense). United States troops gathered evidence of the illegal activities. This evidence should satisfy the objective proof requirement.

120. Convention Relative to the Laying of Automatic Submarine Contact Mines (Hague No. VIIn), opened for signature Oct. 18, 1907, 36 Stat. 2332, T.S. No. 541, 205 Parry's T.S. 331 [hereinafter 1907 Convention]. The United States signed this convention and later ratified it on Noveniber 27, 1909. See infra note 127. For a general discussion of the legal aspects of mining, see D. O'CoNNELL, supra note 92, at 1138-39; Tucker, supra note 103, at 303-05; Thorpe, Mine Warfare at Sea-Some Legal Aspects of the Future, 18 OCEAN DEv. \& INT'L L. 255 (1987). For an American interpretation of the convention notice requirements, see $10 \mathrm{M}$. WHITEMAN, supra note 91 , at 679 80 (commentary by legal advisor to Undersecretary of State Welles).

121. In addition to the 1907 Convention, there are several generally accepted custoniary duties that further limit mining: First, the mines may be laid only in the theater of operation, and the belligerent must provide or mark out safe routes through which merchant vessels may pass without undue hardship or inconvenience. Tucker, supra note 103, at 305. Second, "[t]he fields must be justifiable as a genuine measure of self-defense." Thorpe, supra note 120, at 272-73. Third, minefields may be employed only when they discriminate between legitimate and illegitimate objects of war. 2 G. SCHWARZENBERGER, INTERNATIONAL LAW 417-18 (1968). 
recent pronouncement in the International Court of Justice concerning the mining of the Nicaraguan harbors by the Umited States. ${ }^{123}$ Not one of these sources prohibits use of all inines. None, however, permits use of the type of activated, free-floating mines einployed by Iran. The inexpensive effectiveness of mines in deterring eneiny and neutral shipping has presented great difficulties in obtaining umversal acquiescence to a complete prohibition. ${ }^{124}$ The trend of official decisions, state practice and the development of humanitarian principles, however, have restricted their use as an instrument of naval warfare.

a. The 1907 Hague Convention No. VIII. The 1907 Hague Convention No. VIII is the only convention governing mining. The teruns of the Convention are relevant because Iran's predecessor, Persia, signed the 1907 Hague Convention but never ratified it. ${ }^{125}$ By virtue of its signature, and until it renounces the Convention-which it has not doneIran is under an obligation to comply with at least the spirit of the Convention. ${ }^{126}$ The United States signed and ratified the Convention and is thus bound by its teruns. ${ }^{127}$ In addition, this Convention, like the other 1907 Hague Conventions on the laws of war, is generally considered a statement of the customary rules, defining legal mining actions for all states. ${ }^{128}$

122. Corfu Channel (U.K. v. Alb.), 1949 I.C.J. 4, 22 (Elementary considerations of humanity and freedom of maritime commurication confine the right to mine.).

123. Military and Paranilitary Activities In and Against Nicaragua (Nicar. v. U.S.), 1986 I.C.J. 14.

124. The 1907 Hague Convention conferees recognized, even then, the near impossibility of securing agreement on strict limitations on the use of so inexpensive and effective a wcapon as the mine:

Seeing that, although the existing position of affairs makes it impossible to forbid the employment of automatic submarine contact mines, it is nevertheless desirable to restrict and regulate their employment in order to mitigate the severity of war and to ensure, as far as possible, to peaceful navigation the sscurity to which it is entitled, despite the existence of war.

1907 Convention, supra note 120, 36 Stat. at 2333-34, T.S. No. 541, at 5, 205 Parry's T.S. at 333.

The impossibility posed by the "existing position of affairs" has never changed sufficiently to update the convention. Subsequent efforts to impose further restriction through a new mining convention have failed. Levie, Mine Warfare and International Law, 62 U.S. NAVAL WAR ColleGE, INTERNATIONAL L. STUDIES 271, 275-76 (1980).

125. Persia signed the convention on October 18, 1907. 1907 Convention, supra note 120, 36 Stat. at 2349, T.S. No. 541 at 22, 205 Parry's T.S. at 342.

126. This obligation is known as pacta sunt servanda, that is, agreements of the parties must be observed.

127. The United States signed the collvention on October 18,1907 and ratified it on November 27, 1909. 1907 Convention, supra note 120, 36 Stat. at 2347, 2350, T.S. No. 541, at 20, 23, 205 Parry's T.S. at 340, 343; D. Schindlell \& J. Toman, The LAws of ARMed Conflicts 720 (1981).

128. See, e.g., Department of the Navy, The Commander's Handbook on the LaW of NAVAL OPERATION (NWP 9) $§ 9.2$ (1987). 
The 1907 Convention neither entirely forbids the use of mines nor proscribes where they may be used. It does, however, forbid use of the type of unanchored, long-term activated mines employed by Iran (and perhaps Iraq) in the Persian Gulf. ${ }^{129}$ Unanchored mines are lawfully deployed only if they become mactive within an hour of deployment; ${ }^{130}$ unanchored Iraman mines probably remam active for days if not weeks. The 1907 Convention's failure to limit either the use of mines altogether or areas of the sea where mines can be lawfully deployed renders it somewhat ineffective. The wholesale mining of the seas during the two World Wars demonstrated that the 1907 Convention, standing alone, was not sufficient to protect peaceful merchant shipping. More restrictive prescriptions have consequently grown out of customary practices, as well as the International Court of Justice's opinions in the Corfu Channel decision $^{131}$ and the Nicaragua decision. ${ }^{132}$

b. The Nicaragua decision. It is iromc that the most current opimion from the International Court of Justice on the continued viability and propriety of using mines as a means of conducting hostilities involves a judgment against the United States for the mining of Nicaraguan harbors. ${ }^{133}$ The Court emphasized that primciples more basic than the sparse details of the 1907 Convention governing mining-those of the freedom of navigation and modern, humanitarian law. ${ }^{134}$ The laying of

129. Article 1 of the convention forbids the use of both unanchored contact mines unless they can be rendered harmless one hour after being laid and anchored contact mines unless they become harmless as soon as they break free of their moorings. 1907 Convention, supra note 120 , art. 1, (1) \& (2), 36 Stat. at 2343 , T.S. No. 541, at 15 . Article 2 provides that "[i]t is forbidden to lay automatic contact mines off the coast and ports of the enemy, with the sole object of intercepting commercial shipping." Id. art. 2, 36 Stat. at 2343, T.S. No. 541, at 15. Article 3 requires states to take "every possible precaution" for the security of peaceful shipping when using anchored automatic contact mines. Id. art. 3, 36 Stat. at 2343, T.S. No. 541, at 15-16. Belligerents are required to "undertake to do their utmost to render these mimes harmless within a limited time, and should they cease to be under surveillance, to notify the danger zones as soon as military exigencies permit." Id., 36 Stat. at 2343, T.S. No. 541, at 15-16. Article 4 permits neutrals to mine their own coasts subject to the requirements, mcluding that of notice, of the previous articles. Id. art. 4, 36 Stat. at 2343-44, T.S. No. 541, at 15-16.

130. Id. art. 1, 36 Stat. 2343 , T.S. No. 541, at 15 .

131. Corfu Channel (U.K. v. Alb.), 1949 I.C.J. 4, 22 ("The obligations incumbent upon the Albanian authorities consisted in notifying, for the benefit of shipping in general, the existence of a minefield in Albanian territorial waters and in waming the approaching British warships of the imminent danger to which the minefield exposed them." The court went on to note that the duty of notification emanates, not from the 1907 Convention, but from "elementary considerations of humanity, ... the primciple of the freedom of maritime commumication [,] and every State's obligation not to allow knowingly its territory to be used for acts contrary to the rights of other States.").

132. Military and Paramilitary Activities In and Against Nicaragua (Nicar. v. U.S.), 1986 I.C.J. 14.

133. See supra note 123 and accompanying text.

134. See infra notes $135-36$ and accompanying text. 
mines by one state in the ports or territorial waters of another interferes with the sovereignty of the coastal state and the "right of free access enjoyed by foreign ships." 135 Laying mines on the high seas interferes with the customary freedoms of commumications and maritime coinmerce belonging to all vessels on the high seas. Laying mines in any waters without notification is a breach of international law:

It has already been made clear above that in peacetime for one State to lay mines in the internal or territorial waters of another is an unlawful act; but in addition, if a State lays mines in any waters whatever in which the vessels of another State have rights of access or passage, and fails to give any warning or notification whatsoever, in disregard of the security of peaceful shipping, it commits a breach of the principles of humanitarian law underlying the specific provisions of Convention No. VIII of 1907. Those principles were expressed by the Court in the Corfu Channel case as follows: "certain general and well recognized principles, namely: elementary considerations of humanity, even more exacting in peace than in war."136

The Court specifically reemphasized the customary requirement of notification that exists in addition to and regardless of a state's accession to the 1907 Convention. Thus, Iran's, and possibly Iraq's, mining activities and subsequent failure to notify mariners of its mining activities placed Iran, and possibly Iraq, ${ }^{137}$ in violation of the principles einbodied in the International Court of Justice's latest opimion on the status of mining.

2. The Iranian Minelajing Incident of September 22, $1987 . \quad$ On September 22, 1987, United States special forces located, photographed, then attacked an Iranian vessel unloading mines into an international shipping lane. The Uinited States claimed that

[t] he actions taken by U.S. forces were conducted in the exercise of our right of self-defense under Article 51 of the Umited Nations Charter. Mining of the high seas, without notice and in an area of restricted navigation, is unlawful and a serious threat to world public order and the safety of international maritime commerce. These Iranian actions were taken despite warnings given to the Government of Iran, subse-

135. Military and Paramilitary Activities In and Against Nicaragua (Nicar. v. U.S.), 1986 I.C.J. $14,112$.

136. $I d$.

137. The degree of Iranian responsibility for all mining in the Gulf is a question of fact that will have to be determined if claims for reparations to vessels are ever presented - as they should be. The presentation of claims provides an opportunity to establish the facts, restate or develop the law, determine the guilty party and force the guilty party, through peaceful methods, to make reparations for its illegal conduct. Until the facts are definitely established or admitted, the known facts-that the Iranians were caught laying inines that match inany of those swept from the Gulf, that most of the mines have been discovered on the western side of the Gulf, i.e., not in Iranian waters or Iranian shipping lanes, and that the appearance of the mines in the Gulf is consistent with the Iranian policy of deterring shipping to and from Iraq or its allies-implicate the Iranians as responsible for at least some of the damage. 
quent to the recent mine damage done to the U.S.-flag vessel Bridgeton, that the U.S. Government would take the action necessary to defend U.S. vessels from attacks of this nature. ${ }^{138}$

Whether the United States' claim is justified depends on the requirements of self-defense under article 51 of the United Nations Charter. The exercise of self-defense is limited by three requirenients: (1) that it is a response to a prior armed attack, (2) that it is proportional to the force sought to be repelled, and (3) that it is necessary. 139

a. Responding to a prior armed attack. The first requirement raises two issues: whether minelaying activities can be considered an armed attack and, if so, whether the activities occurred prior in time to the American interception. As one scholar has noted, neither the legislative history nor the language of article 51 itself explains precisely what constitutes an armed attack. ${ }^{140}$ General scholarly opinion considers at a minimum that an armed attack must involve the "illegal use of physical force by the armed forces of the state." 141

Thus, an armed attack has three constituent coniponents: (1) illegal, (2) use of force, (3) by armed forces of the state. As discussed in the previous section, the Iranian mining campaign was conducted in an unlawful nianner-the mines were of a type prohibited by international convention and practices, and mariners were not notified of the location of the fields. ${ }^{142}$ A mine, like other conventional weapons used in armed attacks, achieves its destructive end through the use of force. The end result for a vessel ${ }^{143}$ that has struck a mine is the sanie as if it suffered from another frequent Iranian tactic-missile attack. In either case, the explosion of the device severely dainages both vessel and persoimel. ${ }^{144}$

138. United States Air Strike in the Persian Gulf, 23 WeekLy Comp. Pres. Doc. 1066 (Sept. 28, 1987).

139. See supra note 113.

140. I. Brownlie, INTERNATIONAL LAW AND THE USE OF ForCE By STATES 278-79 (1963).

141. Badr, The Exculpatory Effect of Self-Defense in State Responsibility, 10 GA. J. INT'L \& CoMP. L. 1, 15 (1980) (footnote omitted).

142. See supra text accompanying note 137 .

143. Schachter, The Lawful Resort to Unilateral Use of Force, 10 YAle J. INT'L L. 291, 291 (1985) (A state is justified in resorting to the unilateral use of force "[w] an armed attack on its territory, vessels or military forces." (emphasis added)).

144. Mines and mining fit within the category of weapons the United Nations has classified as capable of being used in an aggressive, and therefore, illegal, manner. Aggression includes: "(b) Bombardment by the armed forces of a State against the territory of another State or the use of any weapons by a State against the territory of another State." Definition of Aggression Resolution, G.A. Res. 3314, art. 3(b), 29 U.N. GAOR Supp. (No. 31) at 142, 143, U.N. Doc. A/9631 (1974). The report accompanying the resolution noted that within article 3(b), " 'any weapons' is used without making a distinction between conventional weapons, weapous of mass destruction and any other kind of weapon." Report of the Special Committee on the Question of Defining Aggression, 29 U.N. GAOR Supp. (No. 19) at 9, U.N. Doc. A/9619 \& Corr. 1 (1974). 
Finally, although it is unclear whether the sailors on the minelayer were part of the Iranian armed forces, the attack falls into a pattern of other Iranian-sponsored attacks as part of its war effort. ${ }^{145}$ Thus, the minelaying is properly characterized as an armed attack.

Justification for considering the minelaying incident as a prior attack is found in the recent history of mining in the Persian Gulf. The Iranian armed attack included not just the mines unloaded in the Gulf that evening but all the prior daniage caused by previous illegal mining activities. Prior attacks caused damage to the U.S.-flagged vessels Bridgeton and Texaco Carribean, as well as to inany other neutral states' vessels. ${ }^{146}$ The continuing illegal mining activities by the Iranians consequently provided continuing opporturities to respond in self-defense. ${ }^{147}$ The armed attack, in other words, cominenced when the Iranians pushed the flist mines into the Gulf.

Reponse to that action was not appropriate, however, until all requirenients of the self-defense fornula were present-the need for immediate action to protect aganist further illegal uses of force. Some might argue that the dispersed mines "attacked" nothing; therefore, the interception was responding to an expectation rather than an actual use of force and was an unjustified, aggressive use of force. ${ }^{148}$ This argument

145. See, e.g., 133 CoNG. REC. E2465, E2465-66 (daily ed. June 17, 1987) (statement of Rep. Aspin) (describing the types of attacks Iran has used during the Gulf war, particularly noting the Pasdaran attacks from naval launches).

146. Caught in the Act, supra note 8 , at 22.

147. The proper timeframe for considering a forceful response to a forceful attack as an action taken in self-defense is a controversial issue, particularly where there is an isolated attack, unlike the situation in the Persian Gulf. There has been considerable discussion on the pennissive boundaries of response-time, but mostly with respect to the issue of whether a state anticipating an attack may act before the attack occurs, see infra note 148. Far less discussion has focused on the difficulties in limiting the after-attack response time. But cf. Schachter, In Defense of International Rules on the Use of Force, 53 U. CH1. L. REV. 113, 132 (1986) ("[T] he idea of self-defense contains a temporal element. It refers to a response made close in time to an attack or imminent threat.... The difficulty of defining a precise time limit-a statute of limitations, as it were-does not impugn the basic idea."); Paust, Responding Lawfully to International Terrorism: The Use of Force Abroad, 8 WHITTIER L. REV. 711, 729-32 (discussing the timing element with respect to the United States bombing of Libya in April 1986). It seems clear, however, that when a state launches a series of attacks, the victim, within the bounds of self-defense, is entitled to respond to any and all attacks to protect itself for as long as the attacks continue.

148. The scope of the right of self-defense under the U.N. Charter is itself subject to divisive debate. Some authors argue that the interplay between articles 2(4) and 51 of the United Nations Charter permits an interpretation that would allow states to respond in self-defense in anticipation of an armed attack (the doctrine of anticipatory self-defense). See, eg., McDougal, The Soviet-Cuban Quarantine and Self-Defense, 57 AM. J. INT'L L. 597, 599-600 (1963). Other authors argue that the Charter restricted the traditional right of self-defense only to those situations where an armed attack has occurred, See, e.g., L. Henkin, How Nations Behave 141 (2d ed. 1979). The author of this note believes the U.S. action in responding to the minelaying incident fits within the latter category and therefore does not require further discussion of competing interpretations. 
ignores the on going realities of the Persian Gulf situation. The match between the mines recovered from the deck of the Iranian vessel and those previously swept from the Gulf provide a clear link to Iran for at least a portion of the damage previously done to merchant vessels in the Gulf. ${ }^{149}$ Given the large number of previously undisclosed mines in the Gulf, it is not improbable that those deployed from the Iranian minelayer would lie hidden as well until triggered by a passing vessel, causing further damage.

b. The proportionate use of repelling force. The second element of the self-defense test requires that the repelling force be proportionalsufficient to deter or halt the illegal event but not so much as to purposely inflict damage on the offending party. ${ }^{150}$ The United States response was proportional. Attacking one vessel in return for the many damaged by undisclosed mines cannot be considered excessive.

c. The necessity of the repelling force. The traditional and enduring formulation of the third elenient, "necessity," requires that the need to use force, "is instant, overwhelming, and leaving no choice of means, and no moment for dehiberation."151 The situation demonstrated that forceful actions were necessary, that evening, to terminate the illegal sowing of mines in the shipping lanes of the Gulf. Umited States troops had to fire on the Iranian minelayer two separate times to halt the sowing activities. ${ }^{152}$ The contmuation of the sowing operation after the first attack made it clear that a warning to halt the activities was not sufficient. Had the mines been deployed, locating and destroying all of them would have been difficult if not impossible.

Reponses through the use of force in self-defense when necessary to deter illegal mining activities demonstrate to states such as Iran that the disturbances of world order are not without a price. The cumulative effect of the convoy activities is to serve notice to Iran and Iraq that the United States and the Allies will continue to require the belligerents to take account of customary and conventional international norms. Iran openly disregarded the standards of the world community and failed to observe the basic obligations coincident with the act of mining. The combination of keeping the seas open despite intimidating and sometimes deadly overtures from both Persian Gulf belligerents, sweeping the area

149. Caught in the Act, supra note 8 , at 22.

150. D. BowetT, SELF-DEFENCE 1N INTERNATIONAL LAW 269 (1958).

151. The Caroline, 2 MOORE, Digest of INTER'National LAW 409, 412 (1906).

152. Caught in The Act, supra note 8, at 22. 
to rid it of mines, and responding when necessary in self-defense sets an important precedent in dealing with difficult and protracted conflicts that can have a substantial impact on the world economy.

\section{CONCLUSION}

The reflagging of the Kuwaiti tankers as a flagging event was a lawful undertaking. The administration was careful to comply with or seek waivers for all documentation requirements. The tenuousness of the link between the tankers and the United States may give rise to skepticism over the degree to which states may abuse the genuine link concept, but such skepticism does not give any state the right to deny the Umited States nationality of the tankers. The right to give a vessel a flag is a sovereign right that cannot now or in the foreseeable future be questioned once a state has decided to proceed with flagging.

The United States used the strength of that conclusion to achieve certain foreign policy goals in the Persian Gulf. Although politics may have dominated the decision to take on the Kuwaiti tankers, the reflagging also served to reinforce the rights of the freedom of the seas and the right of merchant vessels to trade even during times of conflict. There was a particular need for an obvious assertion of neutral rights in the Persian Gulf where one, if not both, of the participants has demonstrated a ready willingness to disregard accepted international norins and ignore paper protests.

Because the United States' presence in the Gulf is so highly visible, is premised on basic international rights, and was mobilized for the purpose of defending those rights, the United States should take care to assure itself and the world commumity that its actions within the Gulf fall within accepted and justifiable international practices. Resort to the unlawful use of force would render the United States' actions just as illegal as those of Iran, deteriorate the rule of law, and set dangerous precedents. In keeping with the spirit of the post-United Nations era, the United States should continue to refrain from retaliatory moves and press for a peaceful settlement of the Persian Gulf war and the claims emanating from the conflict. 